\title{
Physics Problem Solving Skill Based on Students Prior Knowledge
}

\author{
Musika Wati \\ Universityof Lambung Mangkurat \\ Banjarmasin, Indonesia \\ mustika_pfis@unlam.ac.id \\ Chairil Faif Pasani \\ Universityof Lambung Mangkurat \\ Banjarmasin, Indonesia
}

\author{
Dewi Dewantara \\ University of Lambung Mangkurat, ULM \\ Banjarmasin, Indonesia
}

\begin{abstract}
The low average scores of students in the survey indicate the skill of students who are less in the problem-solving process. The student's skill in problem-solving in the learning process be measurable self-assessment and peer assessment.The objective of this research is to describe physics problem-solving skill after controlling student's prior knowledge. This research is a part of the dissertation research that was conducted at SMAN 7 Banjarmasin in 2015. The data were collected using prior knowledge instrument in early of the experiment and using the problem-solving instrument at the end of the experiment. This Study used a quasi-experiment with $2 \times 2$ factorial design (Wati 2016). The data was analyzed using descriptives statistics before calculated using analysis of covariance (ANCOVA).From data analysis, it can be shown that corrected means of (1) students prior knowledge all of thes experimental group was in poor category, (2) physics problem-solving skill of students who followed the the collaborative instructional model and were given peer assessment has the highest level than expository instruction model.
\end{abstract}

Keywords-Problem Solving Skill; Prior Knowledge; collaborative instructional, assessment

\section{INTRODUCTION}

Based on Law of the Republic of Indonesia Number 14 The Year 2005 on Teachers and Lecturers, the definition of the teachers are professional educators with the main task of educating, teaching, guiding, directing, training, assessing, and evaluate students, in early childhood education, formal education, primary education and secondary education.

Physics learning is not just reviewing the available knowledge, however, physics learning will continue to evolve inquiries and the exploration of the universe. Physics is also identical to a process, that: (1) knowledge is a cycle between theory and experiment, (2) theories must be predictable and described, and (3) experiments must be carried out again (reproducible)[1].

A teacher in teaching Physics can not only through lectures only [2], [3]. Physics would be more meaningful if taught by fun learning model, prioritize process rather than a product. Physics can also be integrated into the values of the characters. Because, in the learning process of Physics, especially when carrying out experiments, the character must be trained scientific attitude in students. Scientific attitude includes objective, honest, develop a sense of curiosity, able to work together, responsible, critical, diligent and open minded.

In reality, teachers are still teaching oriented to the achievement of the target material, which is contained in the curriculum. Also, prefers to use the time to give a drill of how to answer the questions based on National Exam (UjianAkhir Nasional), rather than encourage his students to do scientific activities, such as conducting experiments in the laboratory and training students to complete the exercises at the level of higher-level thinking. Things such as this are less training problem-solving abilities, as well as minimizing the student's skill to think creatively. Thus, not surprisingly, South Kalimantan, Banjarmasin especially, has not received a significant achievement in a national event such as the Olympics of Science (Olimpiade Sains Nasional), nor the Physics Olympics.

According to the data disclosed by Lembaga Penelitian dan Pengembangan Direktorat Jenderal Pendidikan Tinggi, the average score of students' science achievement Indonesia ranged between 420-435 of international standard scores, that is 500. This led Indonesia ranked 35th out of 49 countries, who participated in the TIMSS survey (Trends in International Mathematics and Science Study). The questions, which are contained in the TIMSS survey, especially for science, was divided into four domains, namely: $35 \%$ of biology, chemistry $20 \%$, 25\% 20\% Physical and earth science[4]. Each of the above domains is divided into three cognitive domains, that is $35 \%$ knowledge, $35 \%$ of the application, and $30 \%$ reasoning. The process of delivering knowledge, application to be able to give a reasoning for the phenomenon, are part of the problemsolving skill. The low average scores of students in the survey indicate the skill of students who are less in the problemsolving process.

Problem-solving skill requires one or more processes to think on a higher order. This thinking process is called problem-solving thinking[5].

Polyadistinguish between questions regular and nonregular[6]. Problems regular, merely an exercise that can be 
solved by using rules or algorithms. Meanwhile, non-regular questions more challenging and requires a level of creativity and originality than solve the problem. Well-structured problems are the presentation of the tasks, which laid out clearly; all the information necessary for solving the problem is given, and usually, there is only one correct answer (closedresponse task) as well as the procedures that have been taught in the classroom. However, well-structured problems often do not reflect the authentic problems, which experienced students in real life. "Most authentic are ill-structured problems" [5].

Problem-solving is a process of understanding the problem, designing a plan for the solution, implementing the plan and evaluating the plan within the framework of solving the real problem [7]. Problems in Physics is not just a mathematical calculation, as has been widely practiced by the teacher. Yet further, the application of physics in everyday life is one important part of critical thinking, creative problem-solving and finding authentic.

There are five troubleshooting steps: (1) visualizing the problem, (2) describe the problem in terms of Physics, (3) planning solution, (4) implementing the plan, (5) examining and evaluating[8].

Problem-solving skill can be trained in learning Physics, in the classroom. One of them through problem-based learning strategies. This learning is designed to improve learning outcomes by asking the students to learn the subject matter through problem-solving. This strategy includes: (1) concentration of the problem, (2) centered on the students, (3) self-directed, student individually or collaboratively is responsible for the process and the subject of learning through self-assessment and peer assessment, (4) self- reflective, reflecting students' understanding of each and learn to adjust their learning strategies [9].

Problem-solving can be trained by collaborative learning model and expository instruction model. Collaborate means to work together with others [10]. Collaborative learning is often associated with cooperative learning. Basically, both collaborative learning and cooperative learning based on constructivist theory, which states that knowledge is built and transformed by the students [11]. In collaborative learning, a student not only within the group but the students have to work in groups. Each student plays an important role and responsibility for learning outcomes friends in the group, in order to achieve a common goal. In the collaborative learning, students work together and share the workload equally, to achieve the desired results[10].

Phases of a model of collaborative learning include: (1) explain the purpose and motivate students, (2) the presentation of information and / or material, (3) organizing students into learning groups, (4) guide the group to work and learn, (5) presentation of the group or test material, (6) the recognition of effort and achievement, both individuals and groups.

Collaborative learning, in the form small groups with a total membership of 4 to 5 students. The placement of students in the study group should be set up by the teacher, with the heterogeneity of the members. Bruffee argues that teachers should not only be monitoring the learning process, otherwise teachers should be able to become a member, as well as students of a community that was looking for the knowledge[10].

Some of the following criteria suitable to be applied in collaborative learning, that: (1) a given task is complex and conceptual, (2) is to want problem-solving, (3) requires creativity or divergent thinking, (4) mastery of concepts and repetition is something that important, (5) the growth of quality of performance, (6) requires critical thinking skills and a high level of argumentation strategies[12].

Another model is the expository instruction model. Expository model of a learning process, in which teachers rely more on verbal skill to present ideas, concepts, principles, generalizations, and facts [13]

According to Jones et al., Cunningham and Jonassen (in [14] expository, tends to create students who are passive, they only wish to receive information and to replicate it on a few things. Learning situation like this requires teachers to provide full information, that is usually accompanied by sample questions. Furthermore, students will be given exercises that course only imitate or changing a few things that have been given in the previous example. In the expository, students rely on a superficial process, such as reading and memorizing[14].

Factual information is easier to learn if the logic is compiled gradually[15]. The subject matter must be delivered from the general to the particular concept so that students can form a cognitive structure and acquire new information. In teacher-centered learning, new information often does not succeed by the students, among other causes is a lack of knowledge of teachers and the lack of skills of teachers in transferring knowledge. According toIheonu[15]the use of expository instruction model, indicated the teacher talk about science while students read about science.

Expository is a teacher-centered learning. This learning, the assumption is the teacher knows everything, while students do not know anything[13]. Teachers tried to deliver what he knows to the students, through talk. Teachers are the speakers, while students are listeners who only speak when called upon to answer questions. Teachers take all decisions, dominated learning, develop learning materials and experiences, order, and ways of disseminating information [13].

In general, expository are often used by teachers through the stages explained, frequently asked questions and at the end of the lesson, the teacher gives a test. Teachers who rely on expository chalk and talk, usually, the process provided by the teacher is reading, discussion and tests[16].

The student's skill in problem-solving in the learning process be measurable by assessment. During this time, to assessing the skill of students, the assessment given by teachers and assessed by teachers. Such assessment forms often do not provide space for students to reflect on their own performance results. In recent years, much research about self-assessment and peer assessment. Both forms of these assessments provide an opportunity for students to get feedback, not only from teachers but also from themselves and friends in their group. 
Development of education is demanding a shift of votes so that today a lot of research to develop assessment during the learning process often known as Class-Based Assessment. This assessment is formative evaluation and to assess various aspects, including cognitive, attitude and performance of students during the learning process. There are various types of assessment in Class-Based Assessment, among others: portfolio, observation sheets science process skills, performance assessment, the self-assessment and peer assessment.

Engaging students participating in the assessment (rating) by Gronlund and Linn [17], can provide several benefits, among others: helping students to (1) better understand the learning objectives, (2) recognize the progress that has done to achieve the goal, (3) effectively diagnose strengths and weaknesses, and (4) develop on upgrading skills in selfassessment (self-evaluation) students. There are various types of assessment peers, but in essence, the use of this assessment want any involvement of students in giving feedback to other students about the quality of their performance.

A peer assessment use trains students to be responsible for learning outcomes, as well as gain insight into their own performance through assessment of the work of his colleagues [18]. So, in addition to training to evaluate the performance of colleagues, students who use this assessment also indirectly be able to compare the results of its performance and the reflection of himself. This was pointed out by The National Foundation for Educational Research in 2007:

"Having assessed the work of others, pupils will find it easier to identify weaknesses in their own work and to see how they can make improvements. They should be encouraged to reflect on their own development and progress, comparing their current work with that produced previously and with their own personal targets".

The implementation assessment of colleagues should pay attention to the following: (1) students must often be trained to practice the ways of this assessment in order to increase confidence in the judge, (2) make sure that the criteria for all parts of the assessment clear and has negotiated with students, (3) give time to cultivate an atmosphere of mutual trust among students, (4) try learning environment is created in an atmosphere of cooperation (collaborative), (5) the provision of symbols and signs to reward and punishment has been agreed[19].

Some advantages of using peer assessment, are: (1) encourage responsibility and involvement of students, (2) encourage the students to reflect on the role and contributions to the group process, (3) the agreement in marking a criterion shows only a little confusion about the results and expectations in a task, (4) focus on improving students' skills in assessing, (5) students are involved in the process and are encouraged to take part in every process, (6) provides more appropriate feedback to students resulting from the assessment of her peers, (7) is considered unfair because students are assessed based on their contributions, (8) when it goes well, it can reduce the burden on teachers to value, (9) can reduce the problem of 'free-rider' because students aware of their participation in the collaboration will be assessed by colleagues[20].
Some deficiencies use of peer assessment, are: (1) the addition of a guidance increase the workload of teachers, (2) allows the value of which increased due to peer pressure or because of friendship, (3) students have a tendency to give the same rating to all friends, (4) students may not want to judge for the status as friends, (5) allows discrimination because students are in groups that fight each other[20].

Things that need to be considered when designing a peer assessment among others: (1) develop a rubric that clearly and accurately to provide standards and criteria on any part of the assessment, (2) give students the opportunity to practice before applying the real assessment, (3) time providing feedback on his involvement, make sure that not only the presence of the rated but involvement [21].

Educational Assessment (educational assessment) is used to determine how good the students' level of achievement [22]. The assessment provides information that can be used as feedback for students, teachers, parents, policy-makers, and the general public about the effectiveness of education. In general, the administration of the assessment carried out in the form of summative evaluation. Summative assessment is typically used to measure the achievement level of knowledge has been obtained by students at the end of the learning, as a condition of the increase in the level or graduation, as well as a selection tool to continue their education to a higher level.

"Self-assessment is a thinking process that provides the learner with a personal guidance system before, during, and after tasks" [23]. Self-assessment helps students to build metacognitive skills that can help them to monitor the skill to think and learn on their own. Besides beneficial for students, self-assessment can also be used by teachers as feedback to determine the development of students' knowledge during learning.

Self-assessment can be used as a continuous process, which is used by students as part of learning[24]. It can be trained teachers through tasks that are equipped with a structured selfassessment, after a meeting of students could be asked to make an assessment of its performance freely through narrative. Andrade and Du [19]state that self-assessment is the formative assessment process for students reflect and evaluate the quality of work and learning, assessing the level of achievement based on the criteria and objectives, identify strengths and weaknesses and improve their performance.

"Student Self-Assessment is the key to stronger student motivation and higher achievement" [25]. That is to say, the implementation of self-assessment can motivate students in learning achievement.

The implementation process of the self-assessment by Boud[19], requires the following: (1) Clarity reason, what is the purpose of the activity of this assessment, (2) the procedures set out clear, students should know what is expected of teachers on their performance, (3) make sure the students that the goal of the assessment is to provide feedback and improvements, so that students are not afraid to give a true assessment, (4) the confidence of each student must be built and affirmed that cheating and collusion can be detected and prevented. 
Johnson and Johnson [18], suggested some parameters for the self-assessment, among others: (1) present on time in class, (2) is ready to participate in learning, (3) is able to complete all the tasks on time, (4) learn and work with high quality, (5) contribute to the group, (5) to request assistance or provide assistance if needed, (6) explain step by step clearly on the task at hand, (7) establish logical reasons, (8) capable of connecting learning with prior knowledge, (9) were able to present a visual on what is learned, (10) volunteered to share the knowledge about the project.

Some advantages of using assessment peers, is also a benefit assessment use themselves, among others: (1) promote the involvement and responsibility of students, (2) encourage students to reflect on the role and contribution during group work, (3) focus on developing students' skills in judging[20].

Therefore, it should be described specifically about the prior knowledge of students before the treatment is applied. As well, described the physics problem-solving skill of students after learning design is applied. "Prior knowledge is one of the most influential factors in student learning because of new information is processed through the lens of what one already knows, believes, and can do" [26].

Prior knowledge, according to Beyer [27] is the innate knowledge of students to the school in a variety of fields already owned students through both academic and experience of real life. Students are said to learn when they are able to relate new information to the knowledge that has with him. Prior knowledge of students is a combination that includes attitudes, experience, and knowledge[28]. Prior Knowledge of students basically are not only related to the subject matter alone but more than that there are various dimensions associated with prior knowledge [27], it is as expressed by:

"Prior or background knowledge does not just refer to subject-matter knowledge. It can also be known in different dimensions, such as metacognitive processes, comprehending strategies, vocabularies, skills, and even self-understanding".

Specifically, four types of students' prior knowledge, are (1) knowledge in particular content, (2) intellectual skills, (3) epistemological beliefs, and (4) metacognitive knowledge [26].

According to Hailikari [29], prior knowledge can be defined as the knowledge that: (a) consists of knowledge declarative and procedural knowledge, (b) be present before the learning process in the classroom, (c) is available or can be remembered or reconstructed, (d) relevant for the achievement of the objectives of the learning task, (e) arranged in a structured scheme, (f) used for other learning tasks, ( $g$ ) is dynamic.

Thus, the objective of this research is to describe physics problem-solving skill after controlling students prior knowledge of the collaborative learning model and the expository instruction model by self-assessment and peer assessment.

\section{METHOD}

The method used is a quasi-experimental, because the study sample is derived from a class that has been formed. The subject in this study are students in SMAN 7 Banjarmasin. According to [30], "Quasi-experimental research involves the use of intact groups of subjects in an experiment, rather than assigning subjects at random to experimental treatments". The dependent variable (Y) is a physics problem-solving abilities. Using the posttest-only, non-equivalent control group design, the dependent variable is measured only once, ie, after the experiment was completed. Variable treatment is learning model (A) with a variable (B) which is a type of assessment. The learning model being tested is a collaborative learning model (A1) and expository instruction models (A2). For variable treatment $\mathrm{B}$, using peer assessment as $\mathrm{B} 1$ and selfassessment as B2, control variables in this study is the prior knowledge of students (X).

The experimental design used is a $2 \times 2$ factorial design with the constellation as Table I. The study involved the control of student's prior knowledge $(\mathrm{X})$ as covariates and the dependent variable that is the Physics problem-solving skills(Y).

TABLE I. $\quad 2 \times 2$ FACTORIAL DESIGN

\begin{tabular}{|c|c|c|}
\hline $\begin{array}{c}\text { Type of } \\
\text { Assessment (B) }\end{array}$ & \multicolumn{2}{|c|}{ Learning Model } \\
\hline \multirow{2}{*}{$\begin{array}{c}(\mathrm{X}, \mathrm{Y})_{11 \mathrm{k}} \\
\mathrm{k}=1,2, \ldots \mathrm{n}_{11}\end{array}$} & $\mathrm{k}=1,2, \ldots)_{21 \mathrm{k}}$ \\
$\left(\mathrm{B}_{1}\right)$ & $\left.(\mathrm{X}, \mathrm{B})_{12 \mathrm{k}}\right)$ & $\left(\mathrm{A}_{2} \mathrm{~B}_{1}\right)$ \\
\hline & $\mathrm{X}, \mathrm{Y})_{22 \mathrm{k}}$ \\
Self assessment & $\mathrm{k}=1,2, \ldots \mathrm{n}_{12}$ & $\mathrm{k}=1,2, \ldots \mathrm{n}_{22}$ \\
$\left(\mathrm{~B}_{2}\right)$ & $\left(\mathrm{A}_{1} \mathrm{~B}_{2}\right)$ & $\left(\mathrm{A}_{2} \mathrm{~B}_{2}\right)$ \\
\hline
\end{tabular}

Where:

$\mathrm{A}_{1}=$ The group of students who take the collaborative learning models

$\mathrm{A}_{2}=$ The group of students who take the expository instruction models

$\mathrm{B}_{1}=$ The group of students was given a peer assessment

$\mathrm{B}_{2}=$ The group of students was given a selfassessment

$\mathrm{X}=$ Prior knowledge of students

$\mathrm{Y} \quad=$ Physics problem-solving skill

$\mathrm{K}=$ The number of students

$\mathrm{A}_{1} \mathrm{~B}_{1}=$ The group of students who carry out collaborative learning and peer assessment

$\mathrm{A}_{2} \mathrm{~B}_{1}=$ The group of students who carry out expository instruction and peer assessment

$\mathrm{A}_{1} \mathrm{~B}_{2}=$ The group of students who carry out collaborative learning and self-assessment

$\mathrm{A}_{2} \mathrm{~B}_{2}=$ The group of students who carry out expository and self-assessment

Data were analyzed using descriptive statistical analysis.

\section{RESUlts AND DisCUSSION}

The data in this study included two groups: covariates variable data and variable data dependent. Covariate variable data were taken at the beginning of the meeting before the treatment carried out. Variable covariate in this study that the 
prior knowledge of students, while the dependent variable is physics problem-solving abilities.

\section{A. Students Prior Knowledge}

Research data analysis supported by SPSS, a summary of data descriptive statistical analysis results is in Table II.

TABLE II. SUMMARY OF STUDENTS PRIOR KNOWLEDGE DATA

\begin{tabular}{|c|l|c|c|}
\hline \multicolumn{2}{|c|}{} & $\mathbf{A}_{\mathbf{1}}$ & $\mathbf{A}_{\mathbf{2}}$ \\
\hline \multirow{4}{*}{$\mathbf{B}_{1}$} & $N$ & 30 & 30 \\
\cline { 2 - 4 } & $\overline{\bar{X}}$ & 12,13 & 10,27 \\
\cline { 2 - 4 } & $S d$ & 3,014 & 3,483 \\
\cline { 2 - 4 } & Min. & 4 & 4 \\
\cline { 2 - 4 } & Maks. & 21 & 19 \\
\hline \multirow{5}{*}{$\mathbf{B}_{2}$} & $N$ & 30 & 30 \\
\cline { 2 - 4 } & $\overline{\bar{X}}$ & 11,57 & 12,13 \\
\cline { 2 - 4 } & Sd & 3,683 & 4,150 \\
\cline { 2 - 4 } & Min. & 5 & 3 \\
\cline { 2 - 4 } & Maks. & 19 & 21 \\
\hline
\end{tabular}

Where:

$\mathrm{A}_{1}=$ Collaborative learning model

$\mathrm{A}_{2} \quad=$ expository instruction model

$\mathrm{B}_{1}=$ peer assessment

$\mathrm{B}_{2} \quad=$ self-assessment

$N=$ The amount of data

$\bar{X} \quad=$ The average score of students' prior knowledge

$S d=$ standard deviation

Min.$=$ The minimum score

Maks. $=$ The maximum score

Based on the tendency of the data conversion, from the prior knowledge of students, a maximum possible score obtained by the student at 40 and a minimum score of 0 . Then it can be made the qualifying table of data prior knowledge of students, as Table III.

TABLE III. CRITERIA FOR THE PRIOR KNOWLEDGE STUDENTS

\begin{tabular}{|c|l|l|}
\hline No & Criteria & Qualification \\
\hline 1 & $30 \leq \bar{x}$ & Very good \\
\hline 2 & $23,33 \leq \bar{x}<30$ & Good \\
\hline 3 & $16,67 \leq \bar{x}<23,33$ & quite good \\
\hline 4 & $10 \leq \bar{x}<16,67$ & poor \\
\hline 5 & $\bar{x}<10$ & Not good \\
\hline
\end{tabular}

Table III is used to classify students based on the level of qualifications. The data used to create these classifications was taken from the average data prior knowledge of the students. Summary data that has been classified can be seen in Table IV.

TABLE IV. QUALIFICATIONS OF THE PRIOR KNOWLEDGE STUDENTS

\begin{tabular}{|c|c|c|}
\hline & $\mathbf{A}_{1}$ & $\mathbf{A}_{2}$ \\
\hline $\mathbf{B}_{1}$ & $\begin{array}{c}\bar{X}=12,13 \\
\text { poor }\end{array}$ & $\begin{array}{c}\bar{X}=10,27 \\
\text { poor }\end{array}$ \\
\hline $\mathbf{B}_{2}$ & $\begin{array}{c}\bar{X}=11,57 \\
\text { poor }\end{array}$ & $\begin{array}{c}\bar{X}=12,13 \\
\text { poor }\end{array}$ \\
\hline
\end{tabular}

Table IV shows the prior knowledge of students in all groups that are in the category of "poor". This is one indicator of students' characteristics in common, which will then be analyzed further to determine the homogeneity of the data group. An average ratio of prior knowledge of students in each group can be seen in Figure 1.

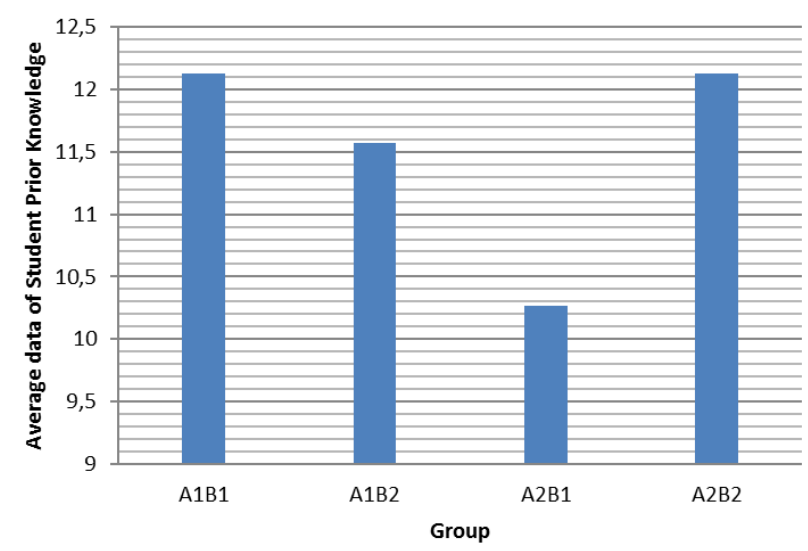

Fig. 1. An average ratio of Student's Prior Knowledge

\section{B. Physics problem-solving skill}

Data from physics problem-solving skills are taken using essay test instruments. As data on students' prior knowledge, this data is analyzed with the aid of a computer program SPSS. The summary descriptive statistical analysis results data as reported in Table $\mathrm{V}$.

TABLE V. SUMMARY OF THE DATA PHYSICS PROBLEM-SOLVING SKILL

\begin{tabular}{|l|l|l|l|}
\hline \multicolumn{2}{|c|}{} & $\mathbf{A}_{1}$ & $\mathbf{A}_{2}$ \\
\hline \multirow{4}{*}{} & $N$ & 30 & 30 \\
\cline { 2 - 4 } $\mathbf{B}_{1}$ & $\bar{Y}$ & 44,67 & 23,20 \\
\cline { 2 - 4 } & $S d$ & 16,198 & 11,028 \\
\cline { 2 - 4 } & Min. & 13 & 9 \\
\cline { 2 - 4 } & Maks. & 76 & 50 \\
\hline \multirow{5}{*}{ B 2} & $N$ & 30 & 30 \\
\cline { 2 - 4 } & $\bar{Y}$ & 27,87 & 35,10 \\
\cline { 2 - 4 } & Sd & 15,065 & 14,728 \\
\cline { 2 - 4 } & Min. & 8 & 14 \\
\cline { 2 - 4 } & Maks. & 60 & 68 \\
\hline
\end{tabular}

Where:

$\mathrm{A}_{1}=$ Collaborative learning model

$\mathrm{A}_{2}=$ expository instruction model

$\mathrm{B}_{1}=$ peer assessment

$\mathrm{B}_{2}=$ self-assessment

$N=$ The amount of data

$\bar{Y}=$ The average score of physics Problem-Solving Skill

$S d=$ standard deviation

Min. $=$ The minimum score

Maks. $=$ The maximum score

The differences physics problem-solving skills of students can be seen in Figure 2. 


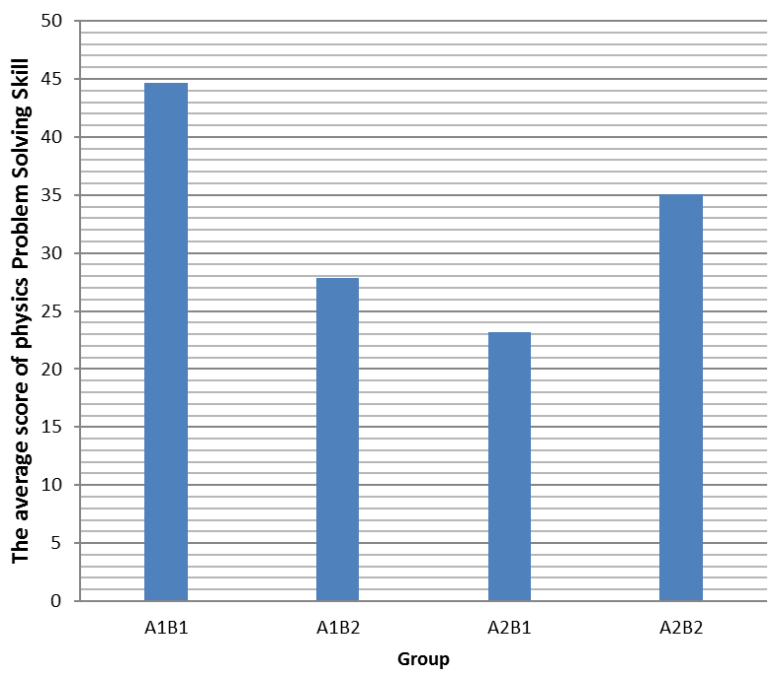

Fig. 2. Physics Problem Solving Skill

\section{CONCLUSION}

Based on the descriptive statistical analysis, it can be shown that the physics students' problem-solving skills, by controlling the prior knowledge of the student group, which follows the model of collaborative learning, accompanied by a peer assessment, obtain better grades than the other three groups interactions. The average of student's physics problem-solving skill score by controlling the prior knowledge of the student group, which follows: (a) the model of collaborative learning, accompanied by a peer assessments 44,67; (b)the model of collaborative learning, accompanied by a selfassessmentis 27,87 ; (c) the model of expository instruction, accompanied by a peer assessment 23,20; and (d) the model of expository instruction, accompanied by a selfassessmentis 35,10 .

\section{REFERENCES}

[1] C. B., Newtonian Physics. California: Fullerton, 2002.

[2] M. Wati, Y. Supriyati, and G. Margono, "Development of Physics Prior Knowledge Instrument for Senior High School Students on Measurement and Vector subject," in Proceeding of The 3rd International Postgraduate Conference in Science and Mathematics 2015(IPCSM'15), 2015.

[3] M. Wati, "Pengaruh Model Pembelajaran dan Jenis asesmen terhadap Kemampuan Pemecahan Masalah Fisika setelah Mengontrol Pengetahuan Awal Siswa," State University of Jakarta, 2016.

[4] M. O. Martin, I. V. S. Mullis, P. Foy, and G. M. Stanco, TIMSS 2011 International Results in Science. Chestnut Hill: TIMSS \& PIRLS International Study Center, 2012.

[5] A. J. Nitko, Educational Assessment of Students. New Jersey: Merill Prentice Hall, 2001.

[6] C. F. Pasani, "Pengembangan Nilai-nilai Kreatif melalui Pembelajaran Matematika berbasis Problem Solving (studi pengembangan di SMP Banjarmasin)," Universitas Pendidikan Indonesia, 2013.

[7] R. L. Custer, B. G. Valesey, and B. N. Burke, "An Assessment Model for a Design Approach to Technological Problem Solving," J. Technol. Educ., vol. 12, 2001.
[8] P. Heller, R. Keith, and S. Anderson, "Teaching Problem Solving through Cooperative Grouping,” Am. J. Phys., vol. 60, 1992.

[9] D. H. Jonassen, Learning to Solve Problems, A Handbook for Designing Problem-Solving Learning Environments. New York and London: Routledge, 2011.

[10]E. E. Barkley, K. P. Cross, and C. H. Major, Collaborative Learning Techniques. Bandung: Penerbit Nusa Media, 2012.

[11]M. Dooly, "Constructing Knowledge Together," in Telecollaborative Language Learning, a guide book to moderating intercultural collaboration online, P. Lang, Ed. Bern, 2008.

[12]D. Preston, "Pair Programming as a Model of Collaborative Learning: a Review of The Research," in Consortium for Computing Sciences in Colleges, 2005.

[13] O. N. Agbulu and E. E. Idu, "The Impact of Participatory and Expository Approaches on Learning of Agricultural Science in Senior Secondary Schools in Benue States," J. Soc. Sci., vol. 16, 2008.

[14] and W. R. van J. J. Swaak, T.de Jong., "The Effects of Discovery Learning and Expository Instruction on The Acquisition of Definitional and Intuitive Knowledge," J. Comput. Assist. Learn., 2004.

[15]N. N. I. Helen, "Effects of guided-inquiry and expository teaching methods on senior secondary school students' performances in Biology in Imo State," J. Educ. Res. Behav. Sci., vol. 2, 2013.

[16]D. Verpoorten, M. Poumay, D. S., and D. Leclercq, "From Expository Teaching to First e-Learning Course Production: Capture in a 17 Online Course Sample of a Pedagogical Pattern Facilitating Transition," in Advanced Learning Technologies, Sixth Internasional conference on IEEE, 2006.

[17] Suratno, "Pengembangan Model Asesmen Teman Sejawat Kompetensi Akuntansi Berbasis Model Pembelajaran Kolaboratif: Uji Empirik pada Mahasiswa Prodi Pendidikan Ekonomi Jurusan Pendidikan IPS - FKIP Universitas Lambung Mangkurat Banjarmasin," State University of Yogyakarta, 2009.

[18]J. Heywood, Assessment in higher Education: Student Learning, Teaching, Programmes and Institutions. Philadelphia: Jessica Kingsley Publishers, 2000.

[19]D. Spiller, Teaching Development. Hamilton: University of Waikato, 2012.

[20]M. Schwartz, "Peer and Self Assessment of Student Work."

[21] R. H. Wesson, Peer and Self Assessment.

[22] J. W. Pellegrino, N. Chudowsky, and R. Glaser, Knowing What Students Know: The Science and Design of Educational Assessment. Washington DC: National Academy Press, 2001.

[23]C. Chapman and R. King, Differentiated Assessment Strategies: One Tool Doesn't Fit All. California: A SAGE Company, 2012.

[24]P. Orsmond, Self and Peer Assessment: Guidance on Practice in the Biosciences. Leeds: Centre for Bioscience, 2004.

[25] J. H. McMillan and H. Jessica, "Student Self-Assessment: The Key to Stronger Student Motivation and Higher Achievement," Educ. HORIZONS, 2008.

[26]S. A. Ambrose and M. C. Lovett, "Prior Knowledge is More Than Content: Skills and Beliefs Also Impact Learning," in Applying Science of Learning in Education, V. A. Benassi, C. E. Overson, and C. M. Halaka, Eds. University of New Hampshire, 2014.

[27]R. G. Belina, Prior or Background Knowledge. Mid-Continent Comprehensive Center.

[28]S. Kujawa and L. Huske, "Strategic teaching and reading project guidebook.” NCREL, 1995.

[29] N. K. Rapi, "Pengaruh Model Pembelajaran dan Jenis Penilaian Formatif terhadap Hasil Belajar IPA setelah Mengontrol Pengetahuan Awal Siswa SMPN di Singaraja," State University of Jakarta, 2014.

[30]W. Wiersma, Research Methods in Education: An Introduction. Massachusetts: Allyn and Bacon, Inc., 1986 